\title{
In vitro evaluation of the temperature increment at the external root surface after Er,Cr:YSGG laser irradiation of the root canal
}

\author{
Marta Abad-Gallegos ${ }^{1}$, Josep Arnabat-Domínguez ${ }^{2}$, Antonio España-Tost ${ }^{2}$, Leonardo Berini-Aytés ${ }^{3}$, Cosme \\ Gay-Escoda ${ }^{4}$
}

\begin{abstract}
${ }^{1}$ Dentist. Resident of the Master of Oral Surgery and Implantology. Barcelona University Dental School
${ }^{2}$ Physician and Stomatologist. Associate professor of Oral and Maxillofacial Surgery. Professor of the Master of Oral Surgery and Implantology. Barcelona University Dental School. Investigator of the IDIBELL Institute

${ }^{3}$ Assistant professor of Oral and Maxillofacial Surgery. Professor of the Master of Oral Surgery and Implantology. Barcelona University Dental School. Investigator of the IDIBELL Institute

${ }^{4}$ Full professor of Oral and Maxillofacial Surgery. Director of the Master of Oral Surgery and Implantology. Barcelona University Dental School. Coordinating investigator of the IDIBELL Institute. Head of the Service of Maxillofacial Surgery, Teknon Medical Center. Barcelona, Spain
\end{abstract}

Correspondence:

Centro Médico Teknon

Instituto de Investigación IDIBELL

C/ Vilana 12

08022 - Barcelona (Spain)

cgay@ub.es

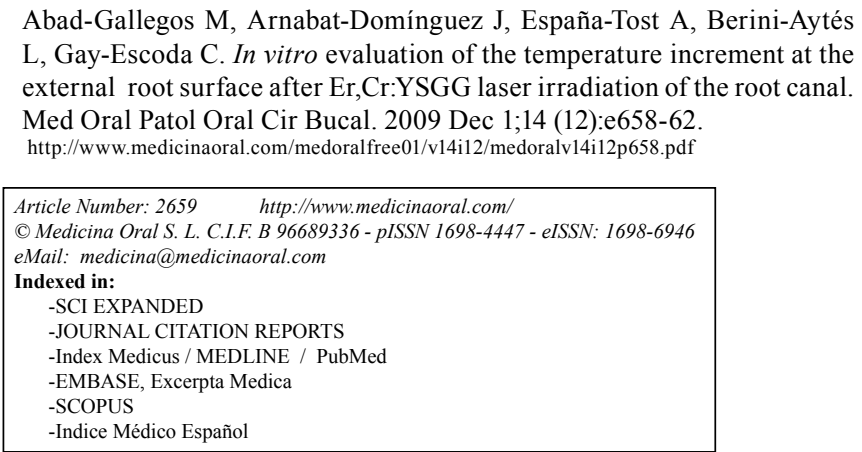

\begin{abstract}
Objectives. A study was made to determine the temperature increment at the dental root surface following Er,Cr:YSGG laser irradiation of the root canal.

Design. Human canines and incisors previously instrumented to K file number ISO 30 were used. Irradiation was carried out with glass fiber endodontic tips measuring $200 \mu \mathrm{m}$ in diameter and especially designed for insertion in the root canal. The teeth were irradiated at 1 and $2 \mathrm{~W}$ for 30 seconds, without water spraying or air, and applying a continuous circular movement (approximately $2 \mathrm{~mm} / \mathrm{sec}$.) in the apico-coronal direction.

Results. At the $1 \mathrm{~W}$ power setting, the mean temperature increment was $3.84^{\circ} \mathrm{C}$ versus $5.01^{\circ} \mathrm{C}$ at $2 \mathrm{~W}$. In all cases the difference in mean value obtained after irradiation versus the mean baseline temperature proved statistically significant $(\mathrm{p}<0.05)$.

Conclusions. Application of the Er,Cr:YSGG laser gives rise to a statistically significant temperature increment at the external root surface, though this increment is probably clinically irrelevant, since it would appear to damage the tissues (periodontal ligament and alveolar bone) in proximity to the treated tooth.
\end{abstract}

Key words: $E r, C r: Y S G G$, endodontics, temperature, root canal, laser. 


\section{Introduction}

One of the main objectives in endodontics is to eliminate all microorganisms from within the root canal, to avoid the spread of pathogens towards the periapical tissues. Instrumentation using files, and the application of antimicrobial agents are the most frequently used methods for reducing or eliminating the presence of microorganisms within the root canal (1).

Other techniques are also currently available for reducing germ presence within the root canal, including the use of different lasers. In this context, the Nd:YAG, Er:YAG, diodes and $\mathrm{CO}_{2}$ lasers are the options most often cited in the literature - emphasis being placed on their bactericidal capacity and physical effects upon the walls of the root canal $(2,3)$.

In 1994, a new type of laser was introduced in dental practice: the Er,Cr:YSGG laser. This system was basically designed for use in dental procedures and in oral surgery. This laser operates in the infrared spectrum at a wavelength of $2.78 \mu \mathrm{m}$ and shows good absorption in water. The first studies made with this type of laser showed it to be able to eliminate hard dental tissues and caries without damaging the surrounding tissues, provided a water spray is used to prevent dentine fusion or carbonization (4). Another of its advantages is that it eliminates dentinal smear and opens the dentinal tubules - thereby leaving the dentinal surfaces optimally prepared for the application of adhesives and composites (5). This laser also affords good results in oral surgery in application to both soft tissues and maxillary bone (6).

The first investigations are currently underway to explore the possible applications of the Er,Cr:YSGG laser in different fields such as periodontics and endodontics. To this effect, a number of fiber glass tips of different diameters and lengths have been developed. The laser tips ideally suited for endodontic practice allow easy insertion within the instrumented root canal, and present a diameter of $200 \mu \mathrm{m}$ with lengths that vary from 14 to $30 \mathrm{~mm}$.

The main objective of laser irradiation of the root canal is to reduce the presence of microorganisms. This bactericidal effect is achieved by the temperature increment within the canal, resulting from the transformation of laser light into heat energy. The bactericidal effect of lasers in general, including the Er,Cr:YSGG system, is of no practical use if the temperature increment induced at the external surface of the root canal is sufficiently important to clinically affect the tooth supporting structures (periodontal ligament and alveolar bone).

The present study investigates the thermal increment recorded at the external root canal surface during application of the new Er,Cr:YSGG endodontic tips. To this effect, different laser power settings and teeth of variable thicknesses were used to furthermore evaluate the possible correlation between tooth type and the corresponding external surface temperature rise.

\section{Material and Methods}

Teeth freshly extracted due to periodontal pathology were employed, stored in physiological saline solution until use. Ten lower incisors and 10 canines were selected (5 each from the upper and lower jaw, respectively). The crown was sectioned with a diamond drill, leaving only the root, which was manually instrumented to one millimeter from the apex using K files (Maillefer, Ballaigues, Switzerland) to file number 30 ISO, and applying $2.5 \%$ sodium hypochlorite solution during instrumentation. After completion of root treatment, the teeth were sterilized in an autoclave (Matachana, Barcelona, Spain) at $134^{\circ} \mathrm{C}$ and two atmospheres, for 5 minutes, with storage in a plastic bag until use.

An Er,Cr:YSGG system was used, consisting of an Yttrium, Scandium and Gallium laser contaminated with Erbium and Chromium (Waterlase, manufactured by Biolase Technologies, San Clemente, CA, USA). This laser operates at a wavelength of $2.78 \mu \mathrm{m}$, with a pulse duration of $140 \mu \mathrm{sec}$ and a frequency of $20 \mathrm{~Hz}$. With this unit, the maximum energy output is $6 \mathrm{~W}$, the amount of water and air being adjustable on a percentage basis from the system panel.

The laser energy was transmitted through an optic fiber to the handpiece. The glass fiber tip used was specifically developed for endodontic practice $(200 \mu \mathrm{m}$ in diameter and $28 \mathrm{~mm}$ in length). No water spray or air was used, i.e., the root canal interior was dry at all times. In this way we aimed to secure the most extreme working conditions with this type of laser.

In order to measure the working length, a rubber stop was fitted to the end of the tip. After determining the working length, the tip was inserted in the canal and the laser was activated at a power setting of either 1 or $2 \mathrm{~W}$, followed by apical displacement of the tip to $1 \mathrm{~mm}$ from the apex (working length), and subsequently moving coronal at a speed of approximately $2 \mathrm{~mm}$ per second This movement was made in a circular manner and repeatedly for 30 seconds, after which irradiation was discontinued in all cases and the resulting temperature increment was measured immediately. The temperature was again recorded 30 seconds after interrupting irradiation.

Temperature measurement was carried out using a type K thermocouple (T Equipment, Hazlet, NY, USA) positioned at the apex. The thermocouple provides a temperature reading established from the potential difference (in $\mathrm{mV}$ ) across the welded ends of two thermoelectric filaments composed of different materials (nickel-chrome and nickel-aluminum, in the case of the K type thermocouple) and the free ends of the filaments. This device is able to measure temperature increments of $0.1^{\circ} \mathrm{C}$. 
For correct utilization of the thermocouple it is essential for the free ends of the thermoelectric filaments to be at a constant (or reference) temperature, with connection to a milivoltmeter indicating the equivalent temperature reading in ${ }^{\circ} \mathrm{C}$. A TM- $1300 \mathrm{~K}$ digital thermometer was used in the present study (T Equipment, Hazlet, NY, USA).

In order to simulate the intraoral environment, the tooth was held between the thumb and index finger, as recommended by Barkhordar et al. (7). In this way we attempted to simulate the presence of periodontal ligament with live tissue (the finger tips of the explorer) maintaining blood microcirculation around the tooth in a way similar to the actual intraoral situation.

The mean temperatures recorded were compared, along with their differences versus the baseline measurements, applying the Student t-test for paired data, with calculation of the corresponding 95\% confidence intervals $(95 \% \mathrm{CI})$. Statistical significance was accepted for $\mathrm{p}<0.05$. The SPSS version 14.0 statistical package was used throughout.

\section{Results}

Table 1 shows the results obtained with the incisors at a laser power setting of $1 \mathrm{~W}$ and a frequency of $20 \mathrm{~Hz}$ applied for 30 seconds. The average temperature increase measured immediately and 30 seconds after irradiation was $3.84^{\circ} \mathrm{C}$ and $1.21^{\circ} \mathrm{C}$, respectively. The same table shows the results obtained with the same teeth at double the power setting $(2 \mathrm{~W})$. The mean temperature increase measured immediately and 30 seconds after irradiation was $5.01^{\circ} \mathrm{C}$ and $1.78^{\circ} \mathrm{C}$, respectively.

Table 2 shows the results obtained with the canines. At a power setting of $1 \mathrm{~W}$, the baseline increment (i.e., determined immediately after irradiation) was $2.48^{\circ} \mathrm{C}$, versus $1.03^{\circ} \mathrm{C}$ measured 30 minutes after irradiation. In turn, the respective mean increments were $3.69^{\circ} \mathrm{C}$ and $1.92^{\circ} \mathrm{C}$ at a power of $2 \mathrm{~W}$.

The differences in temperature increase between canines and incisors were not significant. The experiment was carried out with these two types of teeth with a view to evaluating possible differences in relation to dental thickness. In this sense, the temperature incre-

Table 1. Incisors irradiated at a power of $1 \mathrm{~W}$ and $2 \mathrm{~W}$ for 30 seconds.

\begin{tabular}{|c|c|c|c|c|c|c|}
\hline Temperature & Mean $\left({ }^{\circ} \mathrm{C}\right)$ & $\begin{array}{l}\text { Standard } \\
\text { deviation }\end{array}$ & $\begin{array}{l}\text { Increment } \\
(\text { mean })\left({ }^{\circ} \mathrm{C}\right)\end{array}$ & $\begin{array}{c}\text { Confidence } \\
\text { interval } \\
(95 \%)\end{array}$ & Significance & \\
\hline \multirow{3}{*}{$\begin{array}{l}\text { Incisors irradiated at } \\
1 \mathrm{~W} \text { for } 30 \text { seconds }\end{array}$} & Baseline & 34.81 & 0.48 & & & \\
\hline & Temperature A & 38.66 & 0.78 & 3.84 & $3.48-4.20$ & $p<0.001$ \\
\hline & Temperature B & 36.01 & 0.49 & 1.21 & $1.11-1.31$ & $p<0.001$ \\
\hline \multirow{3}{*}{$\begin{array}{l}\text { Incisors irradiated at } \\
2 \mathrm{~W} \text { for } 30 \text { seconds }\end{array}$} & Baseline & 34.53 & 0.26 & & & \\
\hline & Temperature A & 39.54 & 0.89 & 5.01 & $4.51-5.50$ & $p<0.001$ \\
\hline & Temperature B & 36.31 & 0.52 & 1.78 & $1.49-2.06$ & $p<0.001$ \\
\hline
\end{tabular}

Temperature A: Temperature measured immediately after irradiation.

Temperature B: Temperature measured 30 seconds after irradiation.

Table 2. Canines irradiated at a power of $1 \mathrm{~W}$ and $2 \mathrm{~W}$ for 30 seconds.

\begin{tabular}{|c|c|c|c|c|c|c|}
\hline Temperature & Mean $\left({ }^{\circ} \mathrm{C}\right)$ & $\begin{array}{l}\text { Standard } \\
\text { deviation }\end{array}$ & $\begin{array}{l}\text { Increment } \\
(\text { mean })\left({ }^{\circ} \mathrm{C}\right)\end{array}$ & $\begin{array}{l}\text { Confidence } \\
\text { interval } \\
(95 \%)\end{array}$ & Significance & \\
\hline \multirow{3}{*}{$\begin{array}{l}\text { Canines irradiated at } \\
1 \mathrm{~W} \text { for } 30 \text { seconds }\end{array}$} & Baseline & 34.96 & 0.26 & & & \\
\hline & Temperature A & 37.45 & 0.58 & 2.48 & $2.15-2.81$ & $p=0.001$ \\
\hline & Temperature B & 36 & 0.33 & 1.03 & $0.86-1.19$ & $p=0.019$ \\
\hline \multirow{3}{*}{$\begin{array}{l}\text { Canines irradiated at } \\
2 \mathrm{~W} \text { for } 30 \text { seconds }\end{array}$} & Baseline & 34.72 & 0.38 & & & \\
\hline & Temperature A & 38.41 & 0.62 & 3.69 & $3.26-4.11$ & $p<0.001$ \\
\hline & Temperature B & 36.64 & 0.44 & 1.92 & $1.77-2.06$ & $p<0.001$ \\
\hline
\end{tabular}

Temperature A: Temperature measured immediately after irradiation.

Temperature B: Temperature measured 30 seconds after irradiation. 
ment proved greater in the canines than in the incisors, though in no case was the increment greater than $6^{\circ} \mathrm{C}$. In all cases the differences between the mean postirradiation and baseline temperature increments were statistically significant $(\mathrm{p}<0.05)$.

\section{Discussion}

The advantages of laser irradiation in endodontics comprise the elimination of dentinal smear, the sealing of dentinal tubules, and bactericidal action as a result of the laser-induced heat effect (8). Unfortunately, however, the temperature increment in the dentinal tissues can produce undesirable effects such as cracks or small fissures upon cooling (9). On the other hand, laser action should be restricted to the internal walls of the root canal - without affecting the external surface, since the thermal effect of irradiation could damage the periodontal ligament and supporting bone.

Quantification of the thermal tissue effects of laser irradiation is made by determining the corresponding temperature increment, for which three measurement options are available: thermocouples, infrared pyrometry and infrared cameras. Most experiments published in the literature have employed thermocouples, since the latter are easy to use, inexpensive and highly reliable (7). On the other hand, thermographic studies have also been conducted using infrared cameras - with results similar to those afforded by thermocouples (10).

Bahcall et al. (11) were the first to study the effects of laser irradiation upon the periodontal tissues, in dogs. Their results indicated that the irradiated teeth suffer ankylosis, since lysis of the root cement was observed. It should be pointed out, however, that the power settings used in these experiments were very high. Scaini et al. (12) in turn reported that a temperature increment of over $10^{\circ} \mathrm{C}$ can induce changes in the fibers of the periodontal ligament and even lead to their necrosis. Cohen et al. (13) were more precise in their assessment, since they pointed out that the probability of vitality loss affecting the cementoblasts, periodontal ligament and alveolar bone is practically insignificant in the case of root surface temperature increments of no more than $5^{\circ} \mathrm{C}$.

In relation to these studies $(12,13)$, the temperatures recorded in our study at the external surface of the root canal did not exceed $10^{\circ} \mathrm{C}$ in any case. The only observation of note was the fact that an increment of just over $5^{\circ} \mathrm{C}$ was recorded with the higher power setting $(2 \mathrm{~W})$ in application to some incisors. On the other hand, it should be pointed out that this thermal increment was brief, since in all cases the temperature rise after 30 seconds did not exceed $2^{\circ} \mathrm{C}$, with a return to the initial baseline temperature after approximately two minutes. In our study temperature was determined using the same method as that described by Barkhordar et al. (7), holding the thermocouple and tooth between two fingers in order to simulate the periodontal ligament with its microcirculation.

The temperature rise should be evaluated in teeth with different root thicknesses, since a positive correlation exists between both parameters, as demonstrated by Romero et al. (14). We preferred to use teeth with different dentinal layer thicknesses in order to evaluate the presumed differences in temperature rise. As was expected, significant differences were recorded between the different teeth, since the lower incisors always showed greater temperature elevations than the canines. Similar results were published by Hibst et al. (15), who moreover offered a series of recommendations for Er:YAG laser application according to the root dentinal thickness of the irradiated tooth. Posteriorly, these same authors (16) quantified the temperature increase produced by an Er:YAG laser within the root canal, based on the variation of a series of parameters such as the laser characteristics (power setting, frequency, duration of irradiation), fiber size, fiber displacement velocity after insertion within the canal, and the thickness of the irradiated root.

Rizoiu et al. (17) studied the temperature increment at pulp level both in vivo and in vitro, as a result of Er,Cr:YSGG laser irradiation. They found joint use of an air and water spray to keep the temperature stable, with a $2^{\circ} \mathrm{C}$ reduction in some cases.

At present, information has been obtained on the thermal effect at the external tooth surface after root canal irradiation with different types of laser and involving different operating parameters. Accordingly, Anić et al. (18), using a $\mathrm{CO}_{2}$ laser with a power setting of $1 \mathrm{~W}$ for three seconds, recorded an average temperature increment of $3.80^{\circ} \mathrm{C}$, versus a mean rise of $11.38^{\circ} \mathrm{C}$ on using a $\mathrm{Nd}: Y A G$ laser at a power of $1 \mathrm{~W}$ and $20 \mathrm{~Hz}$ for three seconds. Farge et al. (19), using a Nd:YAP laser, likewise recommended a limit of $200 \mathrm{~mJ} /$ pulse, a pulse duration of $150 \mathrm{~ms}$ and a frequency of $10 \mathrm{~Hz}$ for one second, with an optic fiber $200 \mu \mathrm{m}$ in diameter. As regards the Er:YAG laser, which is the system most similar to the Er,Cr:YSGG laser used in our study, Theodoro et al. (20) showed that an increment of only $2 \cdot 20^{\circ} \mathrm{C}$ is obtained on applying $100 \mathrm{~mJ}$ at $10 \mathrm{~Hz}$ for a maximum of 30 seconds. For this same type of laser, Hibst et al. $(15,16)$ recommended $50 \mathrm{~mJ}$ with frequencies of between $6-15 \mathrm{~Hz}$, in direct relation to the root thickness of the irradiated tooth. In our study with the Er,Cr:YSGG laser, $200 \mu \mathrm{m}$ tips were used, which imply a power loss of approximately $70 \%$. Accordingly, on irradiating at 1 $\mathrm{W}$, the effective power setting is actually $0.3 \mathrm{~W}$. Since a frequency of $20 \mathrm{~Hz}$ was involved in all cases, the effective working energy was $0.5 \mathrm{~W} / 20 \mathrm{~Hz}=0.025 \mathrm{~J}$ (or $25 \mathrm{~mJ}$ ) - i.e., similar to the energy delivered by the Er:YAG laser. 
In conclusion, irradiation of the root canal with the Er,Cr:YSGG laser using $200 \mu \mathrm{m}$ tips at a power setting of either $1 \mathrm{~W}$ or $2 \mathrm{~W}$ for 30 seconds, with continuous circular movements of about $2 \mathrm{~mm} / \mathrm{sec}$, induces a statistically significant but clinically irrelevant temperature increment at the external surface of the root canal, since this increase is not sufficient to damage the neighboring tissues (periodontal ligament and supporting alveolar bone) of the treated tooth.

\section{References}

1. Bystrom A, Sundqvist G. The antibacterial action of sodium hypochlorite and EDTA in 60 cases of endodontic therapy. Int Endod J. 1985;18:35-40.

2. Moritz A, Gutknecht N, Goharkhay K, Schoop U, Wernisch J, Sperr W. In vitro irradiation of infected root canals with a diode laser: results of microbiologic, infrared spectrometric, and stain penetration examinations. Quintessence Int. 1997;28:205-9.

3. Israel M, Cobb CM, Rossmann JA, Spencer P. The effects of $\mathrm{CO}_{2}$, Nd:YAG and Er:YAG lasers with and without surface coolant on tooth root surfaces. An in vitro study. J Clin Periodontol. 1997;24:595-602.

4. Eversole LR, Rizoiu IM. Preliminary investigations on the utility of an erbium, chromium YSGG laser. J Calif Dent Assoc. 1995;23:41-7.

5. Sung EC, Chenard T, Caputo AA, Amodeo M, Chung EM, Rizoiu IM. Composite resin bond strength to primary dentin prepared with Er, Cr:YSSG laser. J Clin Pediatr Dent. 2005;30:45-9.

6. Rizoiu IM, Eversole LR, Kimmel AI. Effects of an erbium, chromium: yttrium, scandium, gallium, garnet laser on mucocutanous soft tissues. Oral Surg Oral Med Oral Pathol Oral Radiol Endod. 1996;82:386-95.

7. Barkhordar RA, Goodis HE, Watanabe L, Koumdjian J. Evaluation of temperature rise on the outer surface of teeth during root canal obturation techniques. Quintessence Int. 1990;21:585-8.

8. Schoop U, Goharkhay K, Klimscha J, Zagler M, Wernisch J, Georgopoulos A, et al. The use of the erbium, chromium:yttrium-scandium-gallium-garnet laser in endodontic treatment: the results of an in vitro study. J Am Dent Assoc. 2007;138:949-55.

9. Yamada MK, Uo M, Ohkawa S, Akasaka T, Watari F. Threedimensional topographic scanning electron microscope and Raman spectroscopic analyses of the irradiation effect on teeth by Nd:YAG, Er: YAG, and CO(2) lasers. J Biomed Mater Res B Appl Biomater. 2004;71:7-15.
10. Keller U, Raab WH, Hibst R. Pulp reactions during Erbium YAG laser irradiation of hard tooth structure. Dtsch Zahnarztl Z. 1991;46:158-60.

11. Bahcall J, Howard P, Miserendino L, Walia H. Preliminary investigation of the histological effects of laser endodontic treatment on the periradicular tissues in dogs. J Endod. 1992;18:47-51.

12. Scaini F, Souza-Gabriel AE, Alfredo E, Da Cruz Filho AM. Temperature variation on the external root surface during intracanal Er:YAG laser irradiation. Photomed Laser Surg. 2008;26:413-7.

13. Cohen BI, Deutsch AS, Musikant BL, Pagnillo MK. Effect of power settings versus temperature change at the root surface when using multiple fiber sizes with a Holmium YAG laser while enlarging a root canal. J Endod. 1998;24:802-6.

14. Romero AD, Green DB, Wucherpfennig AL. Heat transfer to the periodontal ligament during root obturation procedures using an in vitro model. J Endod. 2000;26:85-7.

15. Hibst R, Keller U. Experimental studies of the application of the Er:YAG laser on dental hard substances: I. Measurement of the ablation rate. Lasers Surg Med. 1989;9:338-44.

16. Keller U, Hibst R. Experimental studies of the application of the Er:YAG laser on dental hard substances: II. Light microscopic and SEM investigations. Lasers Surg Med. 1989;9:345-51.

17. Rizoiu I, Kohanghadosh F, Kimmel AI, Eversole LR. Pulpal thermal responses to an erbium,chromium: YSGG pulsed laser hydrokinetic system. Oral Surg Oral Med Oral Pathol Oral Radiol Endod. 1998;86:220-3.

18. Anić I, Tachibana H, Masumoto K, Qi P. Permeability, morphologic and temperature changes of canal dentine walls induced by $\mathrm{Nd}$ : YAG, $\mathrm{CO}_{2}$ and argon lasers. Int Endod J. 1996;29:13-22.

19. Farge P, Nahas P, Bonin P. In vitro study of a Nd:YAP laser in endodontic retreatment. J Endod. 1998;24:359-63.

20. Theodoro LH, Haypek P, Bachmann L, Garcia VG, Sampaio JE, Zezell DM, et al. Effect of ER:YAG and diode laser irradiation on the root surface: morphological and thermal analysis. J Periodontol. 2003;74:838-43.

\section{Acknowledgements:}

This study was carried out by the "Dental and Maxillofacial Disease and Therapeutics" research group of the IDIBELL Institute, with financial support from the teaching-oral surgery healthcare agreement signed by the University of Barcelona, the Consorci Sanitari Integral and the Servei Català de la Salut de la Generalitat de Catalunya (Catalan Health Authorities). 